\title{
Blue economy discourses and practices: Reconfiguring ocean spaces in the Philippines
}

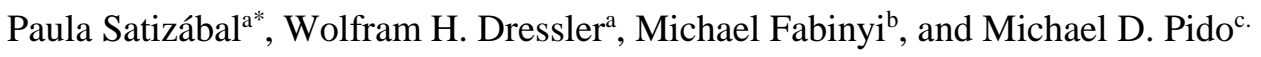

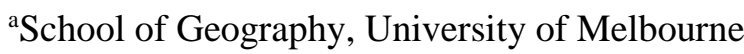 \\ ${ }^{\mathrm{b} F a c u l t y}$ of Arts and Social Sciences, University of Technology Sydney \\ ${ }^{\mathrm{c}}$ Graduate School/Centre for Strategic Policy and Governance, Palawan State University \\ * Corresponding author
}

\section{E-mail addresses}

paula.satizabal@gmail.com (P. Satizábal), wolfram.dressler@unimelb.edu.au (W.H. Dressler), michael.fabinyi@uts.edu.au (M. Fabinyi), m.pido@psu.palawan.edu.ph (M.D. Pido).

\begin{abstract}
Blue economy initiatives have emerged along marine and coastal areas, seeking to bring the green economy into a 'blue world'. Often defined as a global policy agenda, blue economy discourses and practices purportedly aim to generate 'blue growth' by linking poverty reduction, social equality, and marine conservation. While global and national policies have spent decades addressing coastal resource management, broader blue economy discourses and practices seem, on the surface, to promote economic growth strategies for marine conservation. Increasingly, new market-oriented programs and projects aim to tap the financial value of the ocean's 'blue capital', ostensibly fostering income generation and sustainable solutions for conservation finance. Drawing on critical discourse analysis and key-informant interviews across scales, we examine the meanings and practices of the blue economy in Southeast Asia and in the Philippines. As an archipelagic nation, millions of coastal dwellers in the Philippines depend on oceans as a major source of livelihood, food security, and wellbeing. We examine how multilateral institutions, bilateral organisations, state agencies, civil society organisations, and other key actors represent and enact the blue economy discursively and in practice. We find that oceans are being imagined as an open frontier that must be managed and utilised for both conservation and economic purposes. New territorialisation processes are creating new borders and
\end{abstract}


management structures that often bypass social and environmental safeguards, posing a major threat to coastal dwellers. We conclude that by foregrounding economic development and coastal management, more socially just and environmentally sustainable governance approaches are neglected.

\section{Key words}

Blue economy, blue growth, marine governance, frontiers, sustainable development, Philippines

\section{Acknowledgements}

We dedicate this paper to the ocean defenders of the Philippines. This research was supported by an Australian Research Council Discovery Grant (DP180100965). We thank Ched Limsa, Jessie Varquez, Jr., and interview participants for their time, insights, and assistance. We are also grateful to the Editor and two anonymous reviewers whose constructive feedback led to substantial improvement of the manuscript. 


\title{
Blue economy discourses and practices: Reconfiguring ocean spaces in the Philippines
}

\begin{abstract}
Blue economy initiatives have emerged along marine and coastal areas, seeking to bring the green economy into a 'blue world'. Often defined as a global policy agenda, blue economy discourses and practices purportedly aim to generate 'blue growth' by linking poverty reduction, social equality, and marine conservation. While global and national policies have spent decades addressing coastal resource management, broader blue economy discourses and practices seem, on the surface, to promote economic growth strategies for marine conservation. Increasingly, new market-oriented programs and projects aim to tap the financial value of the ocean's 'blue capital', ostensibly fostering income generation and sustainable solutions for conservation finance. Drawing on critical discourse analysis and key-informant interviews across scales, we examine the meanings and practices of the blue economy in Southeast Asia and in the Philippines. As an archipelagic nation, millions of coastal dwellers in the Philippines depend on oceans as a major source of livelihood, food security, and wellbeing. We examine how multilateral institutions, bilateral organisations, state agencies, civil society organisations, and other key actors represent and enact the blue economy discursively and in practice. We find that oceans are being imagined as an open frontier that must be managed and utilised for both conservation and economic purposes. New territorialisation processes are creating new borders and management structures that often bypass social and environmental safeguards, posing a major threat to coastal dwellers. We conclude that by foregrounding economic development and coastal management, more socially just and environmentally sustainable governance approaches are neglected.
\end{abstract}

\section{Key words}

Blue economy, blue growth, marine governance, frontiers, sustainable development, Philippines 


\section{Introduction}

The past three decades have seen a gradual shift from state-led coastal and marine governance to public-private partnerships that leverage bilateral and private sector investments to fund management interventions in oceans globally (Abbott et al. 2014; Brent et al. 2018a; WFFP \& WFF 2017, 2). Under the banner of 'partnerships', these actors and networks forge alliances among donors (multilateral and bilateral, including banking institutions), public agencies, civil society organisations, and private sector institutions (e.g., philanthropic organisations and speculative investors) to generate and influence global and national policy agendas in a so-called 'blue economy' (Barbesgaard 2018).

On the surface, these partnerships are framed and represented as congenial, productive spaces wherein environmentally sustainable solutions can be forged by sharing human, financial, and material resources that can ultimately foster sustainable economic growth in coastal and marine spaces (Abrahamsen 2004). In fusing growth and sustainability, however, the nascent blue economy agenda is intensifying economic investment and extraction in oceans, with the potential to further exclude marginalised actors (Bennett 2018; Bennett et al. 2019; Cohen et al. 2019). In the blue economy, the governance of oceans involves their configuration as 'frontiers', creating boundaries and management interventions to target their full market potential through extraction and/or conservation, often without the participation of coastal dwellers (Choi 2017; Silver \& Campbell 2018; Steinberg 2018; Steinberg \& Kristoffersen 2018).

While studies have examined the global rise of the blue economy, in this paper, we critically engage with blue economy discourse to examine how this global agenda unfolds in Southeast Asia and the Philippines in particular (see Childs \& Hicks 2019; Choi 2017). We show that while there is a clear mandate to exploit and or conserve oceans for state and private sector interests, there is no clear consensus on what the blue economy means or attempts to pursue on the ground, or how it differs from previous coastal and marine program interventions. Unsurprisingly, variously positioned actors understand and engage with the notion in multiple ways (Silver et al. 2015; Voyer et al. 2018), shaping the blue economy agenda in whichever direction they prefer, with potential opportunities in terms of coastal livelihood support, and detrimental outcomes for coastal dwellers linked to 
reclamation, dispossession, and overexploitation (Brent et al. 2018a, 5). Recent research describes emerging blue economy discourse in terms of governing oceans as natural capital and good business (Silver et al. 2015). Others have shown how actors use these discourses to position knowledge production and facilitate economic development, and thereby create new ocean frontiers (Choi 2017; Steinberg \& Kristoffersen 2018). Choi (2017) shows how China's blue economy, for example, involves the state opening and claiming ocean territory as newly governable spaces for resource control and exploitation. Across polar, temperate, and equatorial oceans, others show how the notion of the blue economy is linked to national and regional sustainable development agendas that drive economic growth and resource accumulation (Childs \& Hicks 2019; Steinberg \& Kristoffersen 2018).

In all of these cases, new knowledge, investments, and technologies render oceans as measurable, fixed entities that can be better controlled and managed for 'blue growth' that will somehow reconcile conservation and development in the context of coastal livelihood changes, struggles, and resistance. Building on this work, our paper critically examines how the blue economy is emerging discursively and in practice in the Southeast Asian region and the Philippines. We argue that blue economy actors in the Philippines seek to govern coastal and ocean spaces discursively and materially through processes of territorialisation for the purposes of generating and accounting for business opportunities and natural capital. We examine who benefits from blue economy policies and practices and how grassroots civil society responds in terms of existing and potential impacts for coastal dwellers and the environment.

The Philippines is an archipelagic ocean nation, where millions of coastal dwellers directly depend on oceans as sources of livelihood, food security, and sociocultural well-being (Fig.1). In recent decades, civil society organisations, state agencies, and bilaterals have produced pioneering marine governance interventions, including: the development of marine protected areas (MPAs) (Alcala \& Russ 2006; Maypa et al. 2012), co-management institutions (Pomeroy \& Pido 1995) and ecosystem-based fisheries management (Pomeroy et al. 2010). Many of the same actors now negotiate the blue 
economy as the means to carry forward their programme agendas or directly resist what it represents and aims to do - questioning its political and economic logic and potential to marginalise coastal dwellers.

This paper highlights what has been prioritised and questions what remains neglected, marginalised, and/or missing from current blue economy discourses and practices. Falling in line with discursive narratives linked to notions of oceans as good business and natural capital, we highlight how these discourses and practices produce new management entities and boundaries to enable governance interventions in Southeast Asia. In the Philippines, we examine how these discourses become entangled in national development and sustainability trajectories. We find that dominant blue economy narratives facilitate the transformation of ocean spaces in terms of business and capital, and the supporting territories that enable the privatisation of common property and/or common pool resources. We show that as the broader agenda starts to materialise in the form of projects, infrastructure, and coastal-marine territories, it intersects with coastal struggles over tenure, access, and user rights. Our analysis shows how current discursive constructions and potential material impacts may threaten coastal peoples' use, access, and tenure rights.

In developing our argument, we first introduce our use of a critical discourse analysis and provide an overview of the global configuration of oceans as economic frontiers. We then present a historical review of coastal marine governance approaches facilitating the blue economy agenda in Southeast Asia and the Philippines. Next, we analyse how the blue economy links with pre-existing discourses and practices and how these create new multilateral partnerships that enable the enclosure of ocean spaces that not only overlap with coastal dwellers tenure regimes, but also transcends with the territories of nation states. This involves engaging with networked actors and new ocean concepts that remove social justice dimensions and aim to transform ocean spaces into units, categories and enclosures (e.g., blue carbon, blue capital, and species units). Our analysis highlights the potential impacts these new territorialisation processes pose for coastal dwellers. We therefore call for the explicit recognition of coastal dwellers' rights over their livelihoods, food production, and ocean 
spaces. Such recognition requires that those who steer the blue economy politically foreground marginalised coastal actors' struggles and resistance in national, regional, and local governance decision-making arenas.

\section{Methodological approach}

We draw on a mixed-methods approach involving discourse analysis and key informant interviews across regional, national and local scales in Southeast Asia and the Philippines. We define discourses as "(dominant) ideas, concepts and categorisations in a society that give meaning to reality and that shape the identities, interests, and preferences of individuals and groups" (Arts et al. 2010, 57).

Discourses combine language, text, actions, beliefs, symbols, values, tools, and practices through social interactions where meaning is negotiated (Gee 2011; Widdowson 2004). As such, discourses bring together knowledge, power and language in "practices that systematically form the objects of which they speak" (Foucault 2002, 54). They therefore act to normalise certain ideas, beliefs and social practices in varied institutional settings (Arts \& Buizer 2009). Yet, discourses also manifest materially (Montefrio \& Dressler 2016). Ideas, beliefs, and practices draw financing and territorial demarcation, which further allocates and manages resources as they move across varied geographies (Satizábal \& Dressler 2019).

We conducted a critical discourse analysis of 363 documents, including agency reports, policies, and articles from bilaterals, multilaterals, government agencies, and civil society organisations. These documents are focused on the blue economy, coastal-marine governance frameworks, and management interventions in Southeast Asia and in the Philippines. The lead author also conducted semi-structured interviews ( $\mathrm{n}=35$ : academics (7); multilateral, and bilateral donors (5); national, provincial, and local governments (13); and civil society organisations $\left.{ }^{1}(10)\right)$ across the same range of blue economy actors in the Philippines, from the regional to the local level, in Metro Manila and Palawan Province (i.e., covering Puerto Princesa City, $;$ and the municipalities of Taytay and El Nido).

\footnotetext{
${ }^{1}$ We use the term civil society organisation to encompass non-governmental organisations, people's organisations and other non-state entities outside of the state and private sector.
} 


\section{Global context: The blue frontier}

Since the early 2000s, oceans have emerged as frontiers for investment in tangible and speculative commodities linked to carbon trading, resource extraction, ecosystem services, MPAs, and wildlife (Campbell et al. 2016; Corson et al. 2013). In parallel with the financialisaton of terrestrial resources in the green economy (MacDonald 2013), in the oceans, this shift has similarly emphasised the partitioning and measuring of marine ecosystems and resources in terms of units (e.g., monetary, carbon, stocks, capital, biomass, etc.) under the premise of valuing and 'selling nature to save it' (McAfee 1999). This transition largely responds to narratives of 'oceans crisis' that have restructured access to and control over marine ecosystems and resources through processes of territorialisation that aim to protect and maximise the ocean's economic potential in ways that often ignore coastal fishers' existing tenure, livelihoods, and management practices (Bennett et al. 2015; Franco et al. 2014; Havice \& Zalic 2019). Ocean frontiers thus emerge as fully reconfigured spaces comprised of 
overlapping property rights and territories, new modes of resource extraction, finance and conservation, and contested knowledges and authority that drive commodification, accumulation and contestation over time (Vandergeest 2018).

As Steinberg (2018) notes, ocean frontiers are spaces of both opening and closing; where new opportunities emerge, there are associated processes of enclosure. In parallel, state and non-state actors in the emerging blue economy create new opportunities by drawing on discursive and material practices to facilitate territorialisation and enclosure. As a discursive and material process, territorialisation encloses and controls spaces actively with agents "proscribing or prescribing specific activities within spatial boundaries" (Vandergeest \& Peluso 1995, 388), who is included or excluded from these boundaries, and who can access what within and around them. In the blue economy, we show how actors at different scales render territory both discursively and materially through governance that further enables capital flows; that is, through ideas, policies, technologies, and practices that facilitate the territorialisation of oceans in ways that render complex marine spaces into legible, manageable, and bounded systems (often with new property rights) that enable economic opportunities (e.g., MPAs, fisheries and aquaculture, ecotourism, and infrastructure, etc.).

Discursively forged territories emerge when a set of policy ideas and ideals become hardened, normative, and scripted, causing bureaucrats, managers, and fishers to align with certain political parameters. Each territory materially reflects financial flows, property rights, and other boundary demarcations that physically circumscribe and define ways to behave, what can and cannot be used, and who is included or excluded. The discursive and material work of territorial enclosure, entangles, and sometimes aligns a range of actors and practices to govern newly reconfigured material and social spaces (Steinberg 2018). Ultimately, as we show, the process of governing ocean territory in the blue economy amounts to strategic (re)ordering, regulation, and control over resources, and assigning meanings, values, and actions upon others (Elden 2010, 810). This requires the production of ocean knowledge to support management practices, inform new (legal and institutional) regulatory frameworks and maximise the ocean's economic potential (Steinberg \& Kristoffersen 2018). Drawing on these insights, our paper shows how intensified oceans governance and extraction have emerged 
together to locate and tap the economic potential of marine resources for development under the premise of sustainability (Barbesgaard 2018).

\subsection{Old wine in new bottles? An emerging blue economy agenda}

After the Brundtland Report (1987) popularised and normalised the growth paradigm, sustainable development, a series of major, international events mainstreamed its discursive and practical applications. At the Rio Earth Summit, for example, Agenda 21 (1992) promoted the notion of publicprivate partnerships as being central in the transition toward sustainable development. The World Business Council for Sustainable Development, a network of over 200 international companies, soon promoted the participation of businesses in global fora on sustainable development. So began the reconfiguration of nature in terms of good business (Sullivan 2017).

Costanza et al. (1997) further facilitated the economistic framing of nature as natural capital in global institutions, think tanks and, eventually, governments, and civil society organisations. Globally, actors started speaking the language of natural capital and the green economy, particularly in terms of natural assets, stocks, and environmental services. Natural capital accounting initiatives soon proliferated, with the United Nations (UN) releasing the System of Environmental-Economic Accounting in 1993, which became the main framework for incorporating natural capital accounts as part of national macroeconomic indicators. In 2000, the UN Millennium Development Goals pushed for poverty reduction between 2000 and 2015, by integrating sustainable development into national policies (Target 7A), and for reducing biodiversity loss (Target 7B) through the expansion of MPAs and other territories (Horigue et al. 2012). These goals reinforced the idea of 'win-win' scenarios for delivering biodiversity conservation and poverty reduction (Adams \& Hutton 2007). In 2006, The Nature Conservancy, the World Wildlife Fund and Stanford University launched the Natural Capital Project, advocating for natural capital as central to environmental protection (Fletcher et al. 2018), and, in 2007, the global initiative known as The Economics of Ecosystems and Biodiversity was launched to "mak[e] nature's values visible", mainstreaming natural capital accounting into state and corporative decision-making arenas (TEEB 2008, 7). In 2012, during the Third UN Conference on 
Sustainable Development (Rio+20), the financial sector released the Natural Capital Declaration, committing to integrate natural capital into financial products and services.

Ocean natures and governance have only recently been reframed as natural capital and good business. Since Rio+20, the 2012 East Asian Seas Congress (in Changwon, Republic of Korea) and the 2013 First World Oceans Summit (organised by The Economist) pushed for both themes to be incorporated into ocean governance under a blue economy frame: "a practical ocean-based economic model using green infrastructure and technologies, innovative financing mechanisms and proactive institutional arrangements for meeting the twin goals of protecting our oceans and coasts and enhancing its potential contribution to sustainable development, including improving human well-being, and reducing environmental risks and ecological scarcities" (Changwon Declaration 2012). Purportedly pursuing blue growth through triple-win strategies, the 2012 Congress and 2013 Summit prompted investors to protect nature through new enclosures and market instruments to mitigate climate change and curb biodiversity loss, while creating business opportunities to foster economic and social benefits. Replacing the 2000 Millennium Development Goals in 2015, the Sustainable Development Goals further endorsed using public-private partnerships to meet various goals, including Goal 14, involving Life Below Water. As ocean natural capital soon emerged with prominence, the notion of 'blue carbon' began circulating globally. Initially discussed at Rio+20, the carbon sequestration potential of marine ecosystems was framed as blue carbon, where the potential of carbon trading and other market schemes for climate change mitigation prevailed (Silver et al. 2015) and aligned with the Paris Agreement (UN Framework Convention on Climate Change, 2015).

\section{Regional blue economies}

Notions of doing good business and drawing on oceans as assets and natural capital predate the emergence of the blue economy in regional Southeast Asia and have laid the platform for national agencies and civil society organisations in different countries to engage blue economy ideals and agendas (Silver et al. 2015). Regionally, the blue economy unfolds in line with two, long-standing, ocean governance trajectories: one of economic development focusing on efficiency and expanding 
ocean economies in terms of good business; and sustainability centring on using markets to support and facilitate biodiversity conservation, broadly in line with natural capital. In many respects, however, the blue economy reflects a continuation of previous ocean governance interventions- $\mathrm{a}$ rebranding that emphasises privatisation and marketisation processes, which capture further investment opportunities and outcomes (Cabral \& Aliño 2011; Mansfield 2004; WFFP \& WFF 2017). As one government official noted: "In principle it really is nothing new to us, [...] we thought it is a good branding for what we are already doing" (No.22, July 31, 2018). It is these broader agendas and practices of the blue economy that influence regional initiatives and national agendas in the Philippines to ultimately facilitate alignment and territorial enclosure in ocean frontiers.

\subsection{Regional Blue business}

Insular Southeast Asia's blue economy agenda was initially influenced by the Partnerships in Environmental Management for the Seas of East Asia (PEMSEA). Emerging in 1994 as a regional Integrated Coastal Management program under the Global Environment Facility and UN Development Programme, it has played a key role in facilitating the expansion of blue economy ideals and practices. PEMSEA has provided capacity-building training to plan and manage Integrated Coastal Management programmes, aiming to coordinate policy, management efforts and governance interventions directed towards the sustainable use of coastal marine ecosystems in the East Asian region (Shujog \& PEMSEA 2015, 12). With a broad network of civil society organisations and state and private partners in 11 Southeast Asian countries, PEMSEA first publicly engaged the notion of the blue economy in a forum in 2011, calling for the scaling up of Integrated Coastal Management so as to build a blue economy agenda (Dongying Declaration).

In line with PEMSEA, the Southeast Asian Fisheries Development Centre has worked as an autonomous, intergovernmental body promoting fisheries development in Southeast Asia. In this sense, it supports and enables other regional partnerships with different local project interventions. For example, it has worked with the Coral Triangle Initiative (CTI) on Coral Reefs, Fisheries, and Food Security across the Philippines and five other island states as a multilateral partnership in 
support of marine biodiversity conservation. The initiative was founded in 2007 and focuses on the sustainable management of marine resources in the Coral Triangle region through the protection of marine biodiversity and food security to mitigate climate change impacts. The Philippine government and the World Wildlife Fund hosted in 2010 the first CTI Regional Business Forum in Manila, where regional, private sector actors met to discuss the development of profitable and sustainable business opportunities. In 2013, under the explicit theme of A Marriage of Profit and Sustainability, the Forum linked business development to "help create a thriving and bustling blue economy for the Coral Triangle region" (CTI 2013). In the context of new partnerships, these actors reproduce and align with discourses of sustainability and business opportunities so as to focus on growing regional market demands for sustainable seafood (i.e., fishing companies and retailers), tourism and travel operators in specified regions (CTI 2014). Central to the CTI and its partners' approach has been the expansion of territories that host both conservation and business enterprise in coastal and marine spaces (see below).

Following PEMSEA and the Southeast Asian Fisheries Development Centre, the Asia-Pacific Economic Cooperation (APEC) supported a regional blue economy agenda since $2014 .^{2}$ APEC's Oceans and Fisheries Working Group argued that a blue economy approach could enhance economic growth through the sustainable development and conservation of marine resources by involving small and medium enterprises (Xiamen Declaration). In 2015, APEC developed the Iloilo Plan of Action, which positioned the blue economy as central to coastal food security and to fostering 'inclusive' economic growth (Vergel 2017). In accordance, PEMSEA released the Seas of East Asia Knowledge Bank platform and the East Asian Seas Sustainable Business Network to showcase and facilitate investment preparation and opportunities to build a blue economy through scaling up Integrated Coastal Management and supporting Coastal Resource Management Programmes in Southeast Asia and the Philippines (Nayanthara Gamage 2016). Similar to the CTI, these programmes aimed to

\footnotetext{
2 APEC's Ocean and Fisheries Working Group is a regional economic forum for the discussion of ocean management and maritime security through task and working groups. It has facilitated policy reforms and regional programs to accelerate regional economic integration.
} 
establish new territories such as marine protected areas with associated market opportunities linked to sustainability, including ecotourism and sustainable fisheries. In parallel, the United States Agency for International Development (USAID) implemented in 2015 the Oceans and Fisheries Partnership with bilaterals, the Southeast Asian Fisheries Development Centre, and CTI to promote ecosystembased approach to fisheries management, relying on seafood traceability and ecolabelling/certification as strategies to monitor fisheries, labour, and gender dynamics at the coastal zone. This configuration of actors demonstrates how new financing ideas, technologies, and territories converge to work together across scale.

Relying on private sector financing, new political actors, their networks, and business arenas have also aimed to support sustainable fisheries and supply chain management. Amongst these, in 2014, EKO Asset Management Partners, LLC, an investment management and advisory firm, released a report for the 'Sustainable fisheries financing strategies: save the oceans feed the world project' ${ }^{3}$ The EKO report notes that:“[ $[.$.$] actors seeking to protect ocean environments have increasingly turned to$ market-based policies and incentives to better align commercial and conservation objectives. These strategies have included certification schemes, the emergence of eco-brands, small investment funds, and consumer marketing efforts that generate greater demand for sustainably sourced seafood. Market principles also shape the use of rights-based fisheries management, or catch-share systems, which attempt to integrate property rights into fishing access as a way to incentivize better long-term resource stewardship."

Following the EKO's recommendations, in 2014, the Bloomberg Family Foundation (Bloomberg Philanthropies) $)^{4}$ launched the Vibrant Oceans Initiative (Phase I US \$53 million; Phase II (2018) US \$86 million investment) establishing alliances with Oceana and Rare (an environmental NGO) to fund policy reforms and support the creation of stewardship programmes. This initiative worked with

\footnotetext{
${ }^{3}$ See Sullivan (2013) for further discussion on EKO's nature finance on terrestrial ecosystems.

${ }^{4}$ The Bloomberg Family Foundation was created by Michael Bloomberg, the $11^{\text {th }}$ richest person in the world (see Forbes Rank 2018).
} 
Encourage Capital (the combination of Wolfensohn Fund Management, L.P. and EKO) and The

As blue growth and finance approaches for marine conservation emerge in the region, they all point to new investment funds for management and development priorities in ocean spaces. Indeed, there is now a shift from action planning to investment (PEMSEA 2017). We now see regional partnerships, private investors, and multi-donor funds engaging with oceans in terms of multiple economic opportunities and management structures that somehow safeguard resource sustainability through multisectoral agencies (Steinberg \& Kristoffersen 2018). Given that these blue economy programs include most economic practices (World Bank 2016), it remains uncertain how such ocean development frameworks will navigate competing economic interests and how marginal coastal actors will benefit from finance-based interventions.

\subsection{Regional Natural Capitals}

Regionally, major international political alliances have supported the oceans as natural capital discourse(s) and have produced a range of accounting methodologies to translate scientific units and concepts directly into economic knowledge. First, the CTI helped establish MPA networks and ecosystem-based management in the Coral Triangle biodiversity area. Through 'technical working groups' made up of public (state agencies, NGOs, etc.) and private actors (development partners), this facilitated expert knowledge exchange and discussions of finance mechanisms for developing blue 
carbon projects and the economic valuation of marine resources in different protected areas in the region (Bover et al. 2011; De Castro et al. 2017; Silver et al. 2015). Second, the Blue Carbon Initiative was established in 2010 to serve as an international partnership (coordinated by Conservational International, the IUCN and the Intergovernmental Oceanographic Commission of the United Nations Educational, Scientific and Cultural Organisation (UNESCO) for developing management, financial, and policy mechanisms to conserve and restore marine ecosystems with high carbon sequestration. The Initiative created international Science and Policy working groups and aimed to provide science-based support for the significance of what became known as blue carbon ecosystems in climate change mitigation, as well as to integrate blue carbon into international policy frameworks. It also aimed to facilitate income generation from conserving and restoring blue carbon ecosystems by standardising carbon stock assessment methodologies for developing carbon markets and trading schemes. Finally, in 2010 the World Bank launched the Wealth Accounting and the Valuation of Ecosystem Services (WAVES) programme as a broader, global partnership to support the institutionalisation and implementation of national capital accounting using international standards. In 2012, it received US \$9.4 million as a multi-donor trust fund from eight development partners to mainstream natural capital into national policy in four countries, including the Philippines (World Bank 2018b, 67). Similar to the Blue Carbon Initiative, the WAVES alliance centred on standardising natural capital accounting methodologies to enable the emergence of carbon markets. Thus, the alliance mostly worked to build and align the capacity of government agencies with blue economy ideals.

Based on the above, it is clear that multiple and overlapping alliances for blue carbon and natural capital are now being facilitated across Southeast Asia (Crooks et al. 2017), discursively aligning with an ostensive blue economy ideal that fosters economic growth, market expansion, and sustainability measures in ocean frontiers. Biophysical sciences and geospatial modelling are being used to translate fluid and dynamic ocean spaces into abstract static units, creating new representations and understandings of oceans. In facilitating new territorial configurations and using technical approaches to blue carbon governance, partnerships have largely neglected political and economic issues, such as 
marine tenure conflicts and equitable benefit distribution (Pomeroy \& Courtney 2018). However, what do these blue economy initiatives mean in terms of tangible discursive and material impacts in coastal areas? Answering this question requires a closer look at how regional blue governance articulates with national oceans governance in the Philippines and how these initiatives may manifest at the local level.

\section{Emerging Philippine blue economies}

After the Marcos regime ended in 1986, the Philippines embarked on constitutional reforms that decentralised coastal resource management. Donor-assisted civil society organisations and government agencies supported Coastal Resource Management Programmes and the expansion of MPAs (White et al. 2005, 2002), with a strong focus on Local Government Units and the involvement of coastal communities (Local Government Code 1991, Republic Act 7160). ${ }^{5}$ This devolution of authority also involved the ideas and finances of various multilateral and bilateral donors (e.g., World Bank, USAID), environmental NGOs (e.g., Conservation International, World Wildlife Fund) and other civil society organisations (White et al. 2002). A signatory to the 1992 Earth Summit, Agenda 21, the Philippines initially received considerable foreign aid and aligned with public-private 'partnerships' to support the sustainable development of oceans, relying heavily on grassroots civil society organisations to reform policy and provide a labour force for implementing Coastal Resource Management Programmes (Austin 2003; Clarke 1993; Masud \& Yontcheva 2005). ${ }^{6}$

The Fisheries Code of 1998 (Republic Act 8550, amended by the 2015 Republic Act 10654) clarified and strengthened Local Government management roles. Moreover, it supported the use of an Integrated Coastal Management framework and no-take MPAs (along 15 percent (\%) of municipal waters and $10 \%$ of coral reef areas) to which Coastal Resource Management Programmes and

\footnotetext{
5 These projects include: the Marine Conservation and Development Program (1984-1986) funded by USAID; the Fisheries Sector Program (1991-1997) funded by an Asian Development Bank loan; PEMSEA (1994-present) funded by the Global Environment Facility; The Coastal Resource Management Project (1996-2004); and the Fisheries Improved for Sustainable Harvests Project (2004-2010) funded by USAID (White et al. 2005).

${ }^{6}$ Over US \$230 million were invested in coastal resource management between 1974-2000 (36 percent (\%) government appropriations and loan counterparts, 63\% international donors, and 1\% local donors) (White et al. 2005, 272).
} 
Integrated Coastal Management projects aligned (White et al 2005, 2006 - the basis of which came from USAID decades earlier and now from PEMSEA with a stronger market focus. ${ }^{7}$ These regional projects and political alliances have intersected in complex ways with the governance of Local Government Units, coastal-marine management territories, and intensifying patterns of fisheries production (Christie 2004; Christie et al. 2009; Eder 2005).

\subsection{National blue business}

Regional discourses of oceans as good business and natural capital have significantly influenced and aligned with national ocean governance agendas, manifesting in a nascent blue governance regime in the Philippines. When discussing oceans in terms of good business, state agencies, such as the National Economic and Development Authority (NEDA), tend to include all marine economies as part of the blue economy, aligning with PEMSEA and the World Bank. In contrast, however, staff members from the Biodiversity Management Bureau, who are the CTI's national focal point, argued that only economies supporting the sustainable use of marine resources should be included: "I would differentiate the [blue] economy to that which would be able to address the needs to ensure that marine resources continue to exist or will be conserved even as we try to generate revenues" (No. 22, July 31,2018$)$.

While this focus on marine sustainability and biodiversity conservation was shared amongst many environmental civil society organisations, most state agencies aligned with exploiting ocean spaces for good business opportunities. The USAID's Ecosystems Improved for Sustainable Fisheries project (ECOFISH, 2010-2017), for example, provided technical assistance to the national government's aim of translating marine conservation plans into business plans in support of Local Government Units (USAID 2017, 6). As a staff member noted: “We translated management plans into actual [coastal] business plans. This means estimating and translating all the strategies into Pesos and Centavos,

\footnotetext{
${ }^{7}$ PEMSEA defined Integrated Coastal Management or ICM as "A dynamic, multidisciplinary and iterative process to promote sustainable development and management of coastal areas. It covers a full cycle of information collection, planning, decision making, management and monitoring of implementation." (PEMSEA 2015, 7).
} 
'where are you going to get the money to do this', 'how much will it cost', in the smallest details that we could." (No.19, July 27, 2018).

Achieving this has meant establishing stronger networks among civil society organisations, public agencies, and private sector entities that enable new cross-scale public-private partnerships with market-oriented solutions. Since 2016, for example, collaboration among the large tuna exporting company Meliomar Inc., the hotel chain Accord Group Hotels, and Greenpeace Philippines leveraged the Sustainable Seafood Week in Manila to discuss ways to make seafood sustainable, accessible and affordable for more Filipinos. Meliomar Inc., a Swiss-led seafood trading company founded in 2013, created alliances with Rare's global fishery recovery program, receiving, in 2016, a US \$1 million investment from the Meloy Fund for Sustainable Small-Scale Fisheries in Southeast Asia. The transition from solely focusing on seafood production to including sustainable consumption was also reinforced by The sustainable diner: A key ingredient of sustainable tourism project, launched in 2017 by World Wildlife Fund and the Philippine Centre for Environmental Protection and Sustainable Development. Funded by the German government's International Climate Initiative $(€ 3,859,999)$, the project integrates sustainable production, consumption, and waste reduction, aiming to mitigate greenhouse gas emissions in the tourism sector. These initiatives reflect a rise in networked partnerships and a dramatic scaling up of financial value in seafood production under the notion of sustainability.

Similarly, guided by the EKO and funded through the Bloomberg Family Foundation, the 2014 Vibrant Oceans Initiative recently emerged as a potential blue economy blueprint for the Philippines. The Nexus Blue Partnership Strategy (Nexus Blue) served as one such blueprint, a hypothetical US \$34 million public-private investment aiming to reform tuna fishery management (Markham et al. 2016a). It emerged in response to the Philippines' European Union 'yellow card' sanction in 2014, a warning for failing to comply with imported fish product traceability standards used against illegal, unreported, and unregulated fishing. Revoked a year later, this sanction would have reduced at least $40 \%$ of tuna exports, prompting the government to amend the 1998 Fisheries Code in 2015 (with 
Republic Act 10554) to include higher penalties and law enforcement mechanisms (LacsamanaUmengan 2018). If implemented, Nexus Blue would support these changes, including the enforcement of maximum catch limits, improved traceability, fishery-wide vessel registration and infrastructure and operations improvements to the General Santos (in southern Mindanao) tuna trade, in accordance with European seafood market restrictions (Markham et al. 2016a). Reinforced by similar regional ideals, public-private business initiatives are core to the country's blue economy discourses and practices, revealing how civil society and the private sector work together to manage and exploit ocean spaces for higher value production, irrespective of potential penalties. Ocean economies are thus conceived of as being central to increasing national economic development, growth, and security. As a former NEDA staff and academic consultant noted, the country's ocean frontier must be exploited by both the state and private sector (see Angara 2019). The academic consultant stressed: "We have to be industrialised, we have to be an OECD [Organisation for Economic Co-operation and Development] country, anything less in the presence of some of these 'interesting neighbours of ours' is going to impact our national security [...] So, I would love for the conglomerates to develop the maritime sector, because if it is just poor fisherfolk, politically, this is the weakest part of our population, it is unfortunate, but it is our reality." (No.16, July 25, 2018).

Similarly, business discussions on regional and national scales about the blue economy remain focused on economic development. In slight contrast, environmental agencies promote sustainable development and biodiversity conservation but do so by drawing on particular marine economies (e.g., ecotourism, sustainable supply chains, and certification schemes). As explained by one staff member: "Moving towards a blue economy development is like having all these environmentally friendly enterprise developments and other industries that are not destructive of the environment; so, the basic principle behind all this is sustainable development." (No.20, July 30, 2018).

Given that Local Government Units are now being told to promote partnerships with private and business sectors for Integrated Coastal Management implementation (Executive Order No. 533, 
2006) $)^{8}$, the devolution and development of such blue growth initiatives will unfold in certain coastal regions over others (e.g., where tourism already exists or is set to emerge). In a discursive and material sense, the Philippine blue economy only denotes elements that are economically valued and can be managed through territorial enclosures. In this way, the opening of the ocean frontier further intensifies state regulation and public-private investments, which grant private actors a central role in shaping how state oceans governance unfolds.

\subsection{National natural capitals}

Reconfiguring oceans as natural capital has been central to the blue economy agenda across almost all sectors, actors, and scales in the Philippines, and reflects both the discursive and material configuration of governance. In 2011, the Philippines joined one of the most prominent natural capital agendas, the Blue Carbon Initiative, to promote blue carbon projects nationally (Pangilinan 2017). Conservation International played an instrumental role in facilitating the initiative, particularly by organising meetings to support the development of alliances among academics, civil society organisations and donors to work on what is now known as blue carbon science. In turn, the Philippines component of the WAVES (US \$0.7 million) programme unfolded from 2014-2017, aiming to provide technical and financial support to national, natural capital accounting efforts, focusing on mangroves, seagrasses and coral reefs. As a WAVES staff member noted, the program was government-oriented and worked with the NEDA, the Department of Environment and Natural Resources, the Philippine Statistics Authority, and Local Government Units on how to use accounting tools to benefit from blue carbon. Framing these agencies as economic managers of the environment, the WAVES initiative worked to build relationships and align carbon science with government needs.

In 2013, the Capturing Coral Reef \& Related Ecosystem Services project, funded by the Global Environment Facility, the World Bank and the University of Queensland, Australia, received US

\footnotetext{
${ }^{8}$ Executive Order No. 533 was issued in 2006 and signed by former President Gloria Macapagal-Arroyo to mandate that Integrated Coastal Management be adopted as a national strategy to ensure the sustainable development of the country's coastal and marine environment.
} 
\$27.8 million to be implemented from 2013-2018 throughout the Philippines. Aligning with the CTI, the project involved working with local universities and state agencies to implement coastal projects. The project focused on providing technical assistance to governments for valuing ecosystem services, marine planning, business development and behaviour change amongst coastal dwellers, using the municipality of El Nido, Palawan, as a pilot site. It aimed to "unlock the natural wealth of coastlines in the East Asia-Pacific region, in order to enhance livelihoods and food security, improve community health and wellbeing, and sustain coastal ecosystems in the region" (CCRES 2014, 1). Working through the architecture of the 1998 El Nido-Taytay Managed Resource Protected Area (54,000 ha of marine waters, 36,000 ha of land), the project focused on developing technologies for marine planning: spatial tools to map fisheries, clarifying marine territories and estimates for mangroves and seagrass sedimentation; bioeconomic models to simulate different policy scenarios; and an ecosystem-based business development approach to promote local economic development (CCRES 2018). The project outcome amounted to framing ecosystems in terms of business management that is, natural capital as good business. ${ }^{9}$ Other major projects ${ }^{10}$ have continued to promote blue carbon agendas and alliances emerging and facilitating new technical interventions with more detailed oversight, measurement and governance of blue carbon ecosystems, aiming to shape coastal access to and use of marine resources.

Such blue carbon branding hopes to draw business to the coastal zone. These blue carbon/capital discussions have prompted interest at the national and provincial levels in the development of marketbased financing mechanisms, including voluntary blue-carbon markets, National Appropriate Mitigation Actions, Reducing Emissions from Deforestation and forest Degradation, and blue bonds (e.g., De Castro et al. 2017; PEMSEA 2017, 20). Although there are economic interests in developing coastal/marine payments for ecosystem schemes, these remain incipient and limited to the payment of

\footnotetext{
${ }^{9}$ See website videos: https://ccres.net/videos/view/our-people-dr-maya-villaluz and https://ccres.net/videos/view/whatmakes-ccres-different.

${ }^{10}$ For example, the Comprehensive Assessment and Conservation of Blue Carbon Ecosystems and their Services in the Coral Triangle, BlueCARES and its Philippines counterpart project Integrated Assessment and Modelling of Blue Carbon Ecosystem for Conservation and Adaptive Management, IAMBlueCECAM.
} 
tourist fees and fishing permits, with major infrastructure initiatives and private capital controlling most coastal development (Gevaña et al. 2018). The language and technicalities of blue carbon are thus central in enclosing and measuring the fluid dynamics of oceans and coastal peoples.

While contrasting policy agendas and practices exist in the blue economy realm, most are entangled in a pervasive and powerful blue growth narrative. Here, blue growth explicitly encompasses good business and natural capital interventions at the national and subnational levels (Azanza 2017). In this context, then, it is unclear how coastal dwellers will be integrated into program interventions, who will benefit, and how benefits will be more equitably distributed in complex community settings. The crucial question, therefore, arises: For whom is the blue economy?

\section{Blue economy for whom? Civil society organisation responses from below}

Regional and national actors have been remarkably consistent in espousing a narrative of how business ventures, markets, and natural capital accounting can yield blue growth. In this actornetwork, however, many grassroots civil society organisations suggest that the pro-growth narrative has paid limited attention to the rights and livelihoods of coastal dwellers. Many civil society organisations suggest that blue carbon-related livelihood support had yet to materialise, others rejected the concept for fear of coastal peoples losing rights, and others were undecided on the merits of the broader vision. As a civil society organisation staff member explained: “.... we are worried about exploiting or maximising the marine resources, because what we are really after [is] rehabilitation and sustainable use." (No.21, July 30, 2018). Several representatives also cautioned that the notion of a blue economy would facilitate the expansion and further intensification of tourism, commercial fishing, MPAs and other marine economies. Given the limited participation these groups had in good business and natural capital projects, some stressed that intensifying economic activity would only further marginalise coastal dwellers.

More radical civil society organisations completely opposed the blue economy agenda, suggesting it prioritises the economic framing of oceans at the expense of coastal rights. One staff member was 
critical of the blue economy's financial investments in valuing ecosystem services, rather than actually supporting ecosystem protection. When reflecting on the relevance of valuing interventions (e.g., WAVES), the staff member mentioned: "Too much money is being invested in valuing ecosystems that we already know are valuable. Do you think anyone has doubts that coral reefs are valuable? We could be using this money to actually protect these ecosystems and their users." (No.9, August 3, 2018). Similarly, Pamalakaya, the National Federation of Small Fisherfolk Organisations (also part of the World Forum of Fisher Peoples) explicitly opposed the blue economy agenda, claiming it supports foreign interests: "The blue economy will continue and further intensify the policies of liberalisation and privatisation in our marine resources. These are policies of foreign plunder!" (No.75, November 6, 2018) Pamalakaya has contested coastal territorialisation processes, such as reclamation projects (i.e., creating new land from coastal-marine spaces linked to oil exploration, large-scale infrastructure) and marine tourism development. Citing displacement of coastal dwellers, Pamalakaya campaigned against the Leyte Tide Embankment Project, a $27.3 \mathrm{~km}$ long seawall enclosure aiming to protect coastal communities in Leyte from storm surges similar to those of Super Typhoon Haiyan. In 2017, Pamalakaya, Greenpeace, World Wildlife Fund, and Save Philippines Seas also campaigned against an underwater Nickelodeon tourism infrastructure theme park in Palawan. The campaign won and the theme park was subsequently cancelled. Such campaigns entail considerable risk. In the past two years, six members of Pamalakaya actively campaigning against reclamation projects have been murdered. As infrastructure development intensifies, so too does the potential harassment of activists and other members of civil society organisations.

Grassroots organisations' concerns involve protecting the coastal spaces in which marginalised groups reside (and typically have little to no formal, tenurial claim over oceans and coastal areas) from further encroachment by intensifying reclamation projects, for-profit initiatives and even marine protected areas. Their concerns are well founded. For instance, President Duterte's Build, Build, Build program (US \$158 billion, from 2018-2023) for infrastructure development also encompasses reclamation projects in both coastal and marine areas. These initiatives draw heavily on national markets and infrastructure interventions as solutions for ocean governance and management, 
obscuring the need to account for past and present social dimensions, political economies, and coastal rights in poverty alleviation. In this context, the very real potential for sustained ocean grabbing emerges at the expense of the rights of coastal dwellers (Bennett et al. 2015). However, the prospect of countering the impacts of ocean grabbing, and other negative aspects of blue growth, remains constrained by declining funds and short project lifespans ( $\sim 5$ years) that pay staff and partly enable them to act. All grassroots organisations interviewed claimed they experience funding shortages that force them to volunteer for months at a time to support their organisations' agendas, revealing the dependency they have on donor funding and larger organisations that ultimately fund the very blue economy projects they resist.

Yet grassroots organisations have also harnessed the blue economy agenda to mobilise international support by leveraging 'blue justice'- justice at sea, in the context of regional fora and international meetings. In October 2018, during the 3rd World Small-Scale Fisheries Congress held in Chiang Mai, Thailand, community leaders and scientists called for a broader mobilisation in pursuit of blue justice, to connect people to oceans and to address the impacts that blue growth agendas have on coastal dwellers' livelihoods and rights. Participants discussed the meaning and importance of blue justice, questioning how to pursue social and distributive justice, human rights, gender equality, and food security among coastal dwellers in the context of maritime extractive sectors (fisheries, mining, infrastructure, etc.) (TBTI 2018). Distancing themselves from the blue economy agenda, many grassroot organisations including small-scale fishers instead increasingly focus on food sovereignty and blue justice as alternatives (KNTI \& WFFP 2017; WFFP 2018).

\section{Discussion and conclusion}

After decades of civil society and academic scrutiny over the emergence of the green economy and its entanglement with market-oriented governance, capital and extractivism (Corson et al. 2013), similar agendas and practices have emerged in the realm of the 'blue' - that is, ocean frontiers (Barbesgaard 2018; Bennett et al. 2019). In Southeast Asia, the rise of the blue economy aligns with a pervasive market and business logic that influences the language, policies, and governing practices. Those 
driving the blue economy, or simply blue growth, have facilitated new forms of political and economic investments in ocean frontiers, generating (tangible and intangible) commodities and finance linked to carbon trading, marine territories, reclamation, resource extraction, and tourism expansion. The blue economy has thus gone well beyond 'selling nature to save it' (McAfee 1999), establishing discursive and material territories (from MPAs, tourism infrastructure or seawalls) that enable capital expansion with few or limited social and ecological safeguards (see also Silver \& Campbell 2018).

Blue economy discourses and practices have facilitated an emerging 'blue growth' ideal that stabilises and leverages an economistic rationale as the means of securing social and environmental benefits-a triple-win scenario. Rendering technical or simply neglecting the social complexity of oceans, the emerging blue economy narrative foregrounds economic practices for governing access to and control over coastal and marine spaces (Bennett 2019; Li 2007). Indeed, blue economy agendas have emerged discursively and materially as good business and natural capital, as they align with broader growth ideals and enclosures along coasts and in oceans. Regionally and nationally, multilateral and state institutional alliances have actively drawn on oceans as good business, bringing together public and private sector actors pushing for new coastal-marine economies and territories. Considering the longstanding inequalities that have shaped coastal and marine political economies in the region (Eder \& Evangelista 2014; Nevins \& Peluso 2008), it is unclear who will guarantee environmental and social safeguards. Crucially, good business ideals and natural capital ventures intersect to accelerate the realignment of ocean governance in terms of the economic valuation of coastal and marine ecosystems. It is here that the rhetoric of blue carbon intersects with and drives coastal enclosures, markets, and capital.

Broadly, blue economy actors frame social and ecological benefits in economistic ways, which narrow the spectrum of potential alternatives to intensifying economic growth and development in coastal areas. The blue economy paradigm reflects further investments in market-expansion, resource uses and infrastructure development in the coastal and marine zone, and thereby increases the 
potential for displacing coastal dwellers and their fishing grounds, as well as degrading marine ecosystems. New political and economic alliances are being leveraged, allowing powerful, private and public sector actors to influence government policy agendas (Mallin et al. 2019). For instance, Executive Order No. 74 has transferred the power to approve reclamation projects from NEDA to the Philippine Reclamation Authority which is under the Office of President Rodrigo Duterte. This transition from state-driven coastal governance to devolved partnerships has enabled actors in both sectors to strengthen their networks and relationships with larger civil society organisations, state agencies, and Local Government Units, shaping governance interventions in line with economic interests (Campling \& Havice 2018). As the discourse and narrative of the blue economy gradually stabilises among dominant actors across scale, sustained investments in the promise of blue growth, technical interventions, and marine territories may ultimately depoliticise complex coastal problems and struggles (Ferguson 1990; Li 2007). Although blue development and sustainability discourses and practices may vary and contradict each other, they typically constitute one another as expanding markets and capital through the ocean governance strategies in coastal settings (Li 2011). These discourses and practices thus require critical scrutiny. They not only enforce particular meanings and understandings of oceans, but also materialise in ocean frontiers, shaping policies and management practices with real implications for coastal peoples and marine ecosystems (Arts \& Buizer 2009). As shown, few upper level blue economy policies and projects factor in coastal use rights and varied livelihoods and many grassroots civil society organisations remain at odds with the broader vision. In the Philippines, fisher organisations have quickly identified the problematic aspects of the blue economy, critically questioning the blue growth rhetoric, advocating for greater participation of smallscale fishers, indigenous peoples, and women in coastal and marine governance. Yet, coastal dwellers and networked civil society organisations have also drawn on blue economy discourses to progress their own social movements for equity and dignity in the region's seascapes. Joining the global food sovereignty movement, for example, the World Forum of Fisher Peoples has progressed the notion of blue justice as a counter-discourse, responding to the increasing encroachment of public and private sector investments in coastal spaces. Similar movements aim to reclaim coastal and ocean spaces to 
ensure a sovereign right to food systems, not only in terms of access and production, but also in relation to shared histories, heritage, territory, and capacities (see the World Forum of Fisher Peoples' food sovereignty six pillars, KNTI \& WFFP 2017, 3-4). ${ }^{11}$ This requires the development of strategies to support the financial independence of grassroots civil society organisations, particularly given their role in defending coastal livelihoods and ecologies.

In sum, the 'blue economy' reflects a process of governing coastal and marine spaces through discursive and material territorialisation, wherein new partnerships between public and private sector actors forge networks, boundaries and management practices. In a manner similar to 'green economy' practices, blue economy actors and the partnerships emerging between financial institutions, bilaterals and conservation organisations align sustainability ideals with new business opportunities, producing abstract knowledge and practices (financing ideas, technologies, territories) that reorder and rebrand oceans as territories with economic potential. The blue economy agenda will thus likely do more to promote extraction and development in oceans through processes of territorialisation than foster environmental sustainability and safeguard the rights of coastal dwellers. The cross-scale power dimensions that shape regional, national, and subnational political and economic partnerships ensure that coastal dwellers remain peripheral to blue governance interventions. Given the history of social movements in the Philippines, participatory processes that support blue justice still have considerable potential to address equity and inequality through redistribution and guarantees of well-being among coastal dwellers (Leach et al. 2018). Achieving this goal in changing political climates will require that civil society organizations be funded and free to carry out the critical work of empowering coastal dwellers in contested marine spaces, as well as developing accountability mechanisms for socioenvironmental injustices. The current blue economy agenda, therefore, must open political and economic spaces that enable coastal dwellers to legitimately express and defend their needs and desires, as ocean frontiers fill with development and degradation.

\footnotetext{
${ }^{11}$ Another example is the Slow Fish movement, which has started to oppose the blue growth rhetoric, fostering awareness about the importance of fishers as custodians of oceans and resisting the privatisation and enclosure of oceans, as our shared commons (e.g. Slow Fish 'The sea: A common good' (2019)).
} 


\section{Figures}

Fig.1. Map of the Philippines. () Copyright Chandra Jayasuriya. 


\section{References}

Abbott J., J.L. Anderson, L. Campling, R. Hannesson, E. Havice, M.S. Lozier, M.D. Smith, and J.M. Wilberg. 2014. Steering the global partnership for oceans. Marine Resource Economics 29:1-16.

Abrahamsen, R. 2004. The power of partnerships in global governance. Third World Quarterly 25(8):1453-1467.

Adams, W., and J. Hutton. 2007. People, parks and poverty: Political ecology and biodiversity conservation. Conservation and Society 5(2):147-183.

Alcala, A.C., and G.R. Russ. 2006. No-take marine reserves and reef fisheries management in the Philippines: A new people power revolution. Ambio 35:245-254.

Angara, S.M. 2019. Building a blue economy. Retrieved from: https://businessmirror.com.ph/2019/02/08/building-a-blue-economy/. Accessed 29 March 2019.

Arts, B., M. Appelstrand, R. Eba’a Atyi, T. Enters, I. Hamakers, D. Kleinschmit, H. Pülzl, K. Visseren-McGinley, and Y. Yasmi. 2010. Discourses, actors and instruments in international forest governance. Embracing complexity -meeting the challenges of international forest governance. IUFRO World Series 28:57-73.

Arts, B., and M. Buizer. 2009. Forests, discourses, institutions: a discursive-institutional analysis of global forest governance. Forest Policy and Economics 11:340-347.

Austin, R. 2003. Environmental movements and fisherfolk participation of a coastal frontier, Palawan Island, Philippines. PhD Dissertation, University of Georgia, Athens. 
Azanza, R.V., P.M. Aliño, R.B. Cabral, M.A. Juinio-Meñez, E.M. Pernia, R.U. Mendoza, and C.S. Siriban, 2017. Valuing and managing the Philippines' marine resources toward a prosperous oceanbased blue economy. Public Policy 18.

Barbesgaard, M. 2018. Blue growth: saviour or ocean grabbing? The Journal of Peasant Studies 45(1):130-149.

Bennett, N.J. 2019. In political seas: engaging with political ecology in the ocean and coastal environment. Coastal Management 47(1):67-87.

Bennett, N.J. A.M. Cisneros-Montemayor, J. Blythe, J.J. Silver, G. Singh, N. Andrews, A. Calo, P. Christie, A. Di Franco, E.M. Finkbeiner, S. Gelcich, P. Guidetti, S. Harper, N. Hotte, J. N. Kittinger, P. Le Billon, J. Lister, R. López de la Lama, E. McKinley, J. Scholtens, A. Solås, M. Sowman, N. Talloni-Álvarez, L.C.L. Teh, M. Voyer, and U.R. Sumaila. 2019. Towards a sustainable and equitable blue economy. Nature Sustainability 2:991-993.

Bennett, N.J. 2018. Navigating a just and inclusive path towards sustainable oceans. Marine Policy 97:139-146.

Bennett, N.J., H. Govan, and T. Satterfield. 2015. Ocean grabbing. Marine Policy 57:61-8.

Bover, T, T. Mohan, and A. Cruz-Trinidad. 2011. PES 101. The blue economies of the CTI: Gearing for Rio+20. Retrieved from:

http://www.coraltriangleinitiative.org/sites/default/files/resources/PES\%20Learning\%20notes\%204 Oct\%202011 0.pdf. Accessed 29 March 2019. 
Brent, Z., M. Barbesgaard, and C. Pedersen. 2018a. The blue fix: unmasking the politics behind the promise of blue growth. Retrieved from https://www.tni.org/files/publicationdownloads/the_blue_fix_english.pdf. Accessed 29 March 2019.

Brent, Z., M. Barbesgaard, and C. Pedersen. 2018b. The illusion of 'Blue Growth'. Retrieved from https://www.tni.org/en/article/the-illusion-of-blue-growth. Accessed 29 March 2019.

Cabral, R.B., and P.M. Aliño. 2011. Transition from common to private coasts: consequences of privatization of the coastal commons. Ocean \& Coastal Management 54: 66-74.

Campbell, L.M., N.J. Gray, L. Fairbanks, J.J. Silver, R.L. Gruby, B.A. Dubik, and X. Basurto. 2016. Global oceans governance: New and emerging issues. The Annual Review of Environment and Resources 41:517-543.

Campling, L., and E. Havice. 2018. The Global Environmental Politics and Political Economy of Seafood Systems. Global Environmental Politics 18(2):72-92.

CCRES. 2018. Site report El Nido, Philippines. Retrieved from: https://ccres.net/resources/view/elnido-philippines. Accessed 29 March 2019.

CCRES. 2014. Capturing Coral Reef \& Related Ecosystem Services. Retrieved from: https://gci.uq.edu.au/filething/get/172/ccres_project_booklet_final_for_web.pdf. Accessed 29 March $\underline{2019 .}$.

Childs, J., and C.C. Hicks. 2019. Securing the blue: Political ecologies of the blue economy in Africa. Journal of Political Ecology 26: 323-340.

Choi, Y.R. 2017. The Blue Economy as governmentality and the making of new spatial rationalities. 
Dialogues in Human Geography 7(1):37-41.

Christie, P., R.B. Pollnac, E.G. Oracion, A. Sabonsolin, R. Diaz, and D. Pietri. 2009. Back to basics: An empirical study demonstrating the importance of local-level dynamics for the success of tropical marine ecosystem-based management. Coastal Management 37:349-373.

Christie, P. 2004. Marine protected areas as biological successes and social failures in Southeast Asia. American Fisheries Society Symposium 42:155-164.

Clarke, G. 1993. People power? Nongovernmental organizations and Philippine politics since 1986. Philippine Quarterly of Culture and Society 21:231-56.

Corson, C., K.I. MacDonald, and B. Neimark. 2013. Grabbing 'green': markets, environmental governance, and the materialization of natural capital. Human Geography 6(1):1-15.

Costanza, R., R. D’Arge, R. de Groot, S. Farber, M. Grasso, B. Hannon, K. Limburg, S. Naeem, R.V. Oneill, J. Paruelo, R.G. Raskin, P. Sutton, and M. VandenBelt. 1997. The value of the world's ecosystem services and natural capital. Nature 387:253-260.

Crawford, G. 2003. Partnership or power? Deconstructing the 'Partnership for Governance Reform' in Indonesia. Third World Quarterly 24:139-159.

Crooks, S., M. von Unger, L. Schile, C. Allen, and R. Whisnant. 2017. Understanding strategic blue carbon opportunities in the seas of East Asia. Silvestrum Climate Associates for PEMSEA, Conservation International and The Nature Conservancy. 
CTI-CFF. 2014. Coral Triangle Regional Business Forum. Retrieved from:

http://www.ctibusinessforum.net/index.php/page/view/regional-business-forum-events. Accessed 29

March 2019.

CTI-CFF. 2013. The $3^{\text {rd }}$ Coral Triangle Business Forum. Retrieved from:

http://www.ctibusinessforum.net/index.php/page/view/rbf-events/view/696/1. Accessed 29 March 2019.

De Castro, R.C., M.J. Pangilinan, A. Lim, and L. Wallington. 2017. Regional workshop on blue carbon proceedings report. Retrieved from:

http://www.coraltriangleinitiative.org/sites/default/files/resources/Regional CTI BC Workshop Rep ort.pdf. Accessed 29 March 2019.

Eder, J.F., and O.L. Evangelista. 2014. Palawan and its global connections. Manila: Ateneo de Manila University Press.

Eder, J.F. 2005. Coastal resource management and social differences in Philippine fishing communities. Human Ecology 33:397-413.

Elden, S. 2010. Land, terrain, territory. Progress in Human Geography 34(6):799-817

Fabinyi, M., Foale, S., and Macintyre, M., 2015. Managing inequality or managing stocks? An ethnographic perspective on the governance of small- scale fisheries. Fish and Fisheries 16(3):471485.

Ferguson, J. 1990. The anti-politics machine: development, depoliticization, and bureaucratic power in Lesotho. Cambridge: Cambridge University Press 
Fletcher, R., W.H. Dressler, Z.R. Anderson, and B. Büscher. 2018. Natural capital must be defended: Green growth as neoliberal biopolitics. Journal of Peasant Studies 1-28.

Franco, J., N. Buxton, P. Vervest, T. Feodoroff, C. Pedersen, R. Reuter, and M.C. Barbesgaard. 2014. The global ocean grab: A primer. Retrieved from https://www.tni.org/en/publication/the-globalocean-grab-a-primer. Accessed 29 March 2019.

Foucault, M. 2002. The archaeology of knowledge. London: Routledge.

Gee, J. P. 2011. An introduction to discourse analysis 3rd Ed, Pp. 36-41. London: Routledge.

Gevaña, D.T., L.D. Camacho, and J.M. Pulhin. 2018. Conserving mangroves for their blue carbon: insights and prospects for community-based mangrove management in Southeast Asia In Threats to Mangrove Forests Ed. C.Makowski and C.W. Finkl, Pp. 579-588. USA: Springer.

Havice, E., and Zalik, A. 2018. Ocean frontiers: Epistemologies, jurisdictions, commodifications. International Social Science Journal 68:219-235.

Horigue, V., P.M. Aliño, A.T. White, and R.L. Pressey. 2012. Marine protected area networks in the Philippines: Trends and challenges for establishment and governance. Ocean and Coastal Management 64:15-26.

KNTI, and WFFP. 2017. Agroecology and food sovereignty in small-scale fisheries. Retrieved from http://worldfishers.org/wp-content/uploads/2017/09/WFFP.Food .Sov .web .pdf. Accessed 29 March 2019.

Lacsamana-Umengan, D. 2018. Philippines: SSF, clear and present danger. Samudra Report 78:5055. 
Leach, M., B. Reyers, X. Bai, E.S. Brondizio, C. Cook, S. Diaz, G. Espindola, M. Scobie, M. Stafford-Smith, and S.M. Subramanian. 2018. Equity and sustainability in the Anthropocene: a social-ecological systems perspective on their intertwined futures. Global Sustainability 1(e13):1-13.

\author{
Li, T. 2011. Rendering Society Technical. In Adventures in aidland: The anthropology of \\ professionals in international development. Ed. D. Mosse, Pp. 57-80. Berghahn: Oxford.
}

Li, T. M. 2007. The will to improve: Governmentality, development, and the practice of politics. Durham: Duke University Press.

Lund, J.F., Mabele, M.B., Sungusia, E., and Scheba, A. 2017. Promising change, delivering continuity: REDD+ as conservation fad. World Development 89:124-139.

McAfee, K. 1999. Selling nature to save it? Biodiversity and green developmentalism. Environment and Planning D: Society and Space 17:133-54.

MacDonald, K.I. 2013. Grabbing 'Green': Cynical reason, instrumental ethics and the production of 'The Green Economy'. Human Geography 6(1):46-63.

Mallin, M.A.F., D.C. Stolz, B.S. Thompson, and M. Barbesgaard. 2019. In oceans we trust: Conservation, philanthropy, and the political economy of the Phoenix Islands Protected Area. Marine Policy. In press.

Markham, A., K. Wachowicz, and T. O'Shea, 2016a. Investing for sustainable global fisheries.

Retrieved from: http://encouragecapital.com/wpcontent/uploads/2016/01/Executive_Summary_FINAL_1-11-16.pdf. Accessed 29 March 2019. 
Markham, A., K. Wachowicz, and T. O’Shea. 2016b. The Isda Strategy: an investment blueprint for small-scale fisheries in the Philippines. Retrieved from: http://fundingtheocean.org/studies/the-isdastrategy-an-investment-blueprint-for-small-scale-fisheries-in-the-philippines/. Accessed 29 March 2019.

Masud, N., and B. Yontcheva. 2005. Does foreign aid reduce poverty? Empirical evidence from nongovernmental and bilateral aid. Washington, DC: International Monetary Fund.

Maypa, A.P., A.T. White, E. Cañares, R. Martinez, R.L. Eisma-Osorio, P. Aliño, and D. Apistar, 2012. Marine protected area management effectiveness: progress and lessons in the Philippines. Coastal Management 40:510-524.

Montefrio, M.J.F., and W.H. Dressler. 2016. The green economy and constructions of the 'idle' and 'unproductive' uplands in the Philippines. World Development 79:114-26.

Nayanthara Gamage, R. 2016. Blue economy in Southeast Asia: Oceans as the new frontier of economic development. Maritime Affairs: Journal of the National Maritime Foundation of India 12(2):1-15.

Nevins, J., and N.L. Peluso. 2008. Taking Southeast Asia to market: commodities, nature, and people in the Neoliberal age. Ithaca: Cornell University.

Pamalakaya. 2017. APEC's Blue Economy shapes up Palawan underwater project-fisherfolk.

Retrieved from https://pamalakayaweb.wordpress.com/2017/01/13/apecs-blue-economy-shapes-uppalawan-underwater-project-fisherfolk/\#more-1749. Accessed 29 March 2019. 
Pamalakaya. 2015. Bluer than blue economy: Fisherfolk group say no to APEC's Blue Economy strategy. Retrieved from https://pamalakayaweb.wordpress.com/2015/10/07/bluer-than-blueeconomy-fisherfolk-group-say-no-to-apecs-blue-economy-strategy/. Accessed 29 March 2019.

Pangilinan, M.J. 2017. Blue carbon initiatives in the Philippines. In State of the mangrove summit: Southern Luzon Proceedings 1-2 October, Eds. Salmo, S.G III, A.M.T. Favis, M.N.S. Ting, A.B.U. Lim, Pp. 48-49. Manila: Ateneo de Manila University.

PEMSEA. 2017. PEMSEA Taps experts on financing for ocean investment. Retrieved from http://pemsea.org/news/pemsea-partners-tap-international-experts-innovative-financing-oceaninvestment. Accessed 29 March 2019.

PEMSEA. 2015. Integrated Coastal Management (ICM) Code. Retrieved from http://www.pemsea.org/sites/default/files/Doc\%2003a_Annex\%20A_8thPC-\%20ICM\%20Code.pdf. Accessed 29 March 2019.

Pomeroy, R., and C.A. Courtney. 2018. Southeast Asia: Recognise tenure rights. Samudra Report 78:27-29.

Pomeroy, R., L. Garces, M. Pido, and G. Silvestre. 2010. Ecosystem-based fisheries management in small-scale tropical marine fisheries: Emerging models of governance arrangements in the Philippines. Marine Policy 34:298-308.

Pomeroy, R., and M. Pido. 1995. Initiatives towards fisheries co-management in the Philippines: The case of San Miguel Bay. Marine Policy 19(3):199-211.

Satizábal, P. 2018. The unintended consequences of 'responsible fishing' for small-scale fisheries: Lessons from the Pacific coast of Colombia. Marine Policy 89:50-57. 
Satizábal, P., and W.H. Dressler. 2019. Geographies of the sea: negotiating human-fish interactions in the waterscapes of Colombia's Pacific Coast. Annals of the American Association of Geographers 109(6):1865-1884.

Silver J.J., and L.M. Campbell. 2018. Conservation, development and the blue frontier: The Republic of Seychelles' Debt Restructuring for Marine Conservation and Climate Adaptation Program. International Social Science Journal 1-16.

Silver J.J., N.J. Gray, L.M. Campbell, L.W. Fairbanks, and R.L. Gruby. 2015. Tracking Blue Economy and human-oceans discourse at Rio+20. Environmental Development 24:135-160.

Shujog, and PEMSEA. 2015. Investment landscape mapping in East Asia: Integrated Coastal Management and sustainable development of coasts and oceans. Quezon City: PEMSEA.

Steinberg, P.E. 2018. Editorial: the ocean as frontier. International Social Science Journal 68:237240.

Steinberg P.E., and B. Kristoffersen. 2018. Building a blue economy in the Arctic Ocean: Sustaining the sea or sustaining the state? In Politics of sustainability in the Arctic: Reconfiguring identity, space, and time, Eds Pram Gad U. and J. Strandsbjerg, Pp. 136-148. London: Routledge.

Sullivan, S. 2017. Making nature investable: from legibility to leveragability in fabricating 'nature' as 'natural capital'. Science \& Technology Studies 31(3):47-76.

Sullivan, S. 2013. Banking Nature? The spectacular financialization of environmental conservation. Antipode 45(1):198-217. 
USAID. 2017. Ecosystems improved for sustainable fisheries (ECOFISH) project completion report. USA: Tetra Tech.

Vandergeest, P. 2018. Law and lawlessness in industrial fishing: Frontiers in regulating labour relations in Asia. International Social Science Journal 68: 325-341.

Vandergeest, P., and N.L. Peluso. 1995. Territorialization and State Power in Thailand. Theory and Society: Renewal and Critique in Social Theory 24:385-426.

Vergel, J.C. 2017. Current trends in the Philippines shrimp aquaculture industry: A booming blue economy in the pacific. Oceanography and Fisheries Open Access Journal J 5:1-5.

Voyer, M., A. McIlgorm, and K. Azmi. 2018. Shades of blue: What do competing interpretations of the Blue Economy mean for oceans governance? Journal of Environmental Policy \& Planning 20(5):595-616.

WAVES. 2016. Pilot ecosystem account for Southern Palawan. Philippines: World Bank.

WFFP. 2018. Fisher Peoples reject the "Our Ocean Conference" and organize the Ocean's People Conference. Retrieved from http://worldfishers.org/2018/10/25/fisher-peoples-reject-oceanconference-organize-oceans-people-conference/. Accessed 29 March 2019.

WFFP, and WFF. 2017. WFF and WFFP Statement on the SDGs and the UN's Ocean Conference. Retrieved from http://worldfishers.org/wpcontent/uploads/2017/06/WFF.WFFP .statement.NYOC .June .2017.pdf. Accessed 29 March 2019. White, A., E. Deguit, W. Jatulan, and L. Eisma-Osorio. 2006. Integrated coastal management in Philippine local governance: Evolution and benefits. Coastal Management 34:287-302. 
White, A., P. Christie, H. D’Agnes, K. Lowry, and N. Milne. 2005. Designing ICM projects for sustainability: Lessons from the Philippines and Indonesia. Ocean Coastal Management 48:271-296.

White, A.T., C.A. Courtney, and A. Salamanca. 2002. Experience with marine protected area planning and management in the Philippines. Coastal Management 30:1-26.

World Bank. 2018a. World Bank Announces New Global Fund for Healthy Oceans. Retrieved from: https://www.worldbank.org/en/news/press-release/2018/09/26/world-bank-announces-new-globalfund-for-healthy-oceans. Accessed 29 March 2019.

World Bank. 2018b. Wealth Accounting and the Valuation of Ecosystem Services. Annual Report 2019. Retrieved from: https://www.wavespartnership.org/sites/waves/files/kc/WAVES-AnnualReport-2018-web_0.pdf. Accessed 29 March 2019.

World Bank. 2016. Blue economy development framework: growing the blue economy to combat poverty and accelerate prosperity. Retrieved from:

http://pubdocs.worldbank.org/en/446441473349079068/AMCOECC-Blue-Economy-DevelopmentFramework.pdf. Accessed 29 March 2019.

TBTI. 2018. Blue justice: small-scale fisheries are too important to fail! Retrieved from: http://toobigtoignore.net/blue-justice-small-scale-fisheries-are-too-important-to-fail/. Accessed 29 March 2019.

Widdowson, H.G. 2004. Text, context, pretext. Critical issues in discourse analysis, Pp. 1-16. Oxford: Blackwell. 


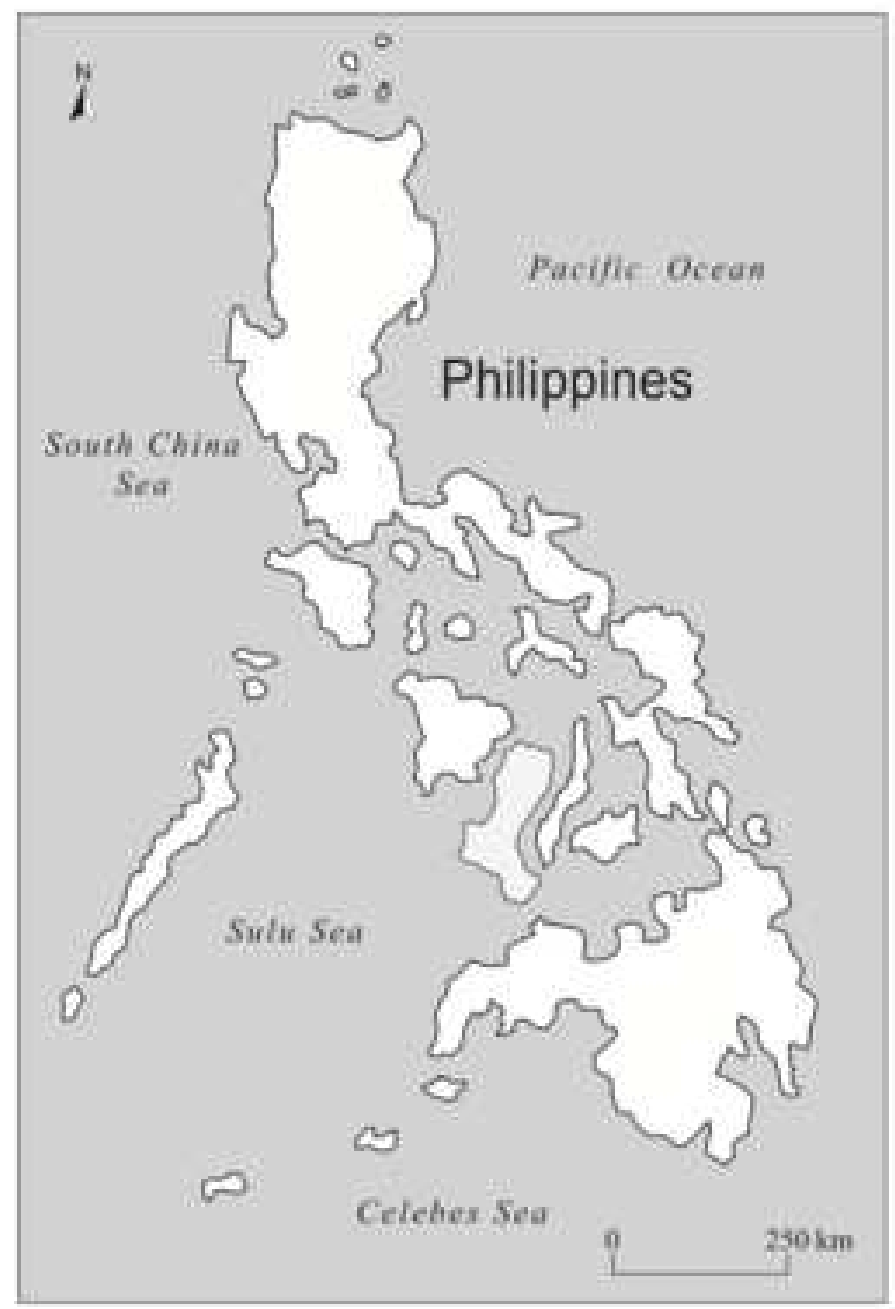

